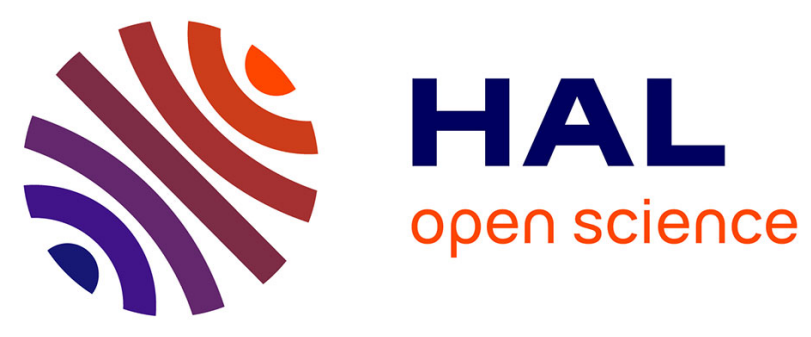

\title{
Developments in the "profil cultural" method for an improved assessment of soil structure under no-till
}

Hubert Boizard, Joséphine Peigné, María Carolina Sasal, Maria de Fátima

Guimarães, Denis Piron, Vincent Tomis, Jean-François Vian, Stéphane S.

Cadoux, Ricardo Ralisch, João Tavares Filho, et al.

\section{To cite this version:}

Hubert Boizard, Joséphine Peigné, María Carolina Sasal, Maria de Fátima Guimarães, Denis Piron, et al.. Developments in the "profil cultural" method for an improved assessment of soil structure under no-till. Soil and Tillage Research, 2017, 173, pp.92-103. 10.1016/j.still.2016.07.007 . hal-01896003

\section{HAL Id: hal-01896003 \\ https://hal-agroparistech.archives-ouvertes.fr/hal-01896003}

Submitted on 15 Oct 2018

HAL is a multi-disciplinary open access archive for the deposit and dissemination of scientific research documents, whether they are published or not. The documents may come from teaching and research institutions in France or abroad, or from public or private research centers.
L'archive ouverte pluridisciplinaire HAL, est destinée au dépôt et à la diffusion de documents scientifiques de niveau recherche, publiés ou non, émanant des établissements d'enseignement et de recherche français ou étrangers, des laboratoires publics ou privés. 


\section{Developments in the "profil cultural" method for an improved assessment of soil structure under no-till}

Hubert Boizard $^{1(*)}$, Joséphine Peigné2, María Carolina Sasal ${ }^{3}$, Maria de Fátima Guimarães ${ }^{4}$, Denis Piron $^{5}$, Vincent Tomis ${ }^{6}$, Jean-François Vian², Stéphane Cadoux ${ }^{7}$, Ricardo Ralisch ${ }^{4}$, João Tavares Filho $^{4}$, Djilali Heddadj ${ }^{8}$, Juan De Battista ${ }^{9}$, Annie Duparque ${ }^{6}$, Julio Cezar Franchini ${ }^{10}$ and Jean Roger-Estrade ${ }^{11}$

${ }^{I}$ INRA, UPR1158 AgroImpact, 80200 Estrées-Mons, France

${ }^{2}$ ISARA-Lyon, 69364 Lyon, France

${ }^{3}$ INTA EEA Paraná, 3101 Oro Verde Entre Rios, Argentina

${ }^{4}$ Agronomy Department, Londrina State University, C. P. 10011, 86057-970 Londrina, Brazil

${ }^{5}$ Université de Rennes 1, UMR EcoBio, 35380 Paimpont, France

${ }^{6}$ Agro-Transfert Ressources et Territoires, 80200 Estrées-Mons, France

${ }^{7}$ Terres Inovia, 78850 Thiverval-Grignon, France

${ }^{8}$ Chambres d'agriculture de Bretagne, 56009 Vannes, France

${ }^{9}$ INTA EEA Concepción del Uruguay, 3260 Concepción del Uruguay, Argentina

${ }^{10}$ Embrapa Soja, C. P. 231, 86001-970 Londrina, Brazil

${ }^{11}$ Université Paris-Saclay, UMR Agronomie, 78850 Thiverval-Grignon, France

*Corresponding author: hubert.boizard@gmail.com

\section{ABSTRACT}

In France, agronomists have studied the effects of cropping systems on soil structure using a field method that is based on a visual description of the soil structure. This "profil cultural" method was 
designed as a field diagnostic tool to identify the effects of tillage and compaction on soil structure dynamics. It is of great benefit to agronomists seeking to improve crop management and preserve soil structure and fertility.

However, the "profil cultural" method was developed and has mainly been used in conventional tillage systems with regular ploughing. As there has been an increase in the use of various forms of reduced, minimum and no-tillage systems in many parts of the world, it is necessary to re-evaluate this method's ability to describe and interpret soil structure dynamics in no-till or reduced tillage. In these situations, changes in soil structure over time are mainly driven by compaction and by regeneration through natural agents (climatic conditions, root growth and macrofauna), therefore it is important to evaluate the effects of these natural processes on soil structure dynamics.

These concerns have led to adaptations and amendments to the initial method based on field observations and experimental work in different cropping systems, soil types and climatic conditions. The description of crack types has been improved and a criterion of biological activity based on the visual examination of clods has been introduced.

To test this modified method, a comparison with the initial method was undertaken and its ability to make diagnoses tested in five experiments in France, Brazil and Argentina. The adapted method allowed an improved assessment of the impact of cropping systems on soil functioning when natural processes were integrated into the description.

Keywords: soil visual examination, soil structure, soil profile, platy soil structure, biological activity, bioturbation

\section{Introduction}

There are many soil visual assessment methods (SVA) used directly in the field to evaluate soil structure. These are of great use to agronomists and consultants when making soil management decisions related to soil structure. SVA techniques can be categorised into two kinds of methods: 
spade methods and profile methods (Boizard et al., 2005; Batey et al., 2015). Spade methods are easy and quick to implement and are easily replicated, while profile methods allow a more detailed structural assessment. The "profil cultural" method is based on a soil profile evaluation directly in the field. The concept was proposed by Henin et al. (1969) to analyse the effects of tillage, compaction and weathering on soil structure and the impact of soil structure on plant development and growth. To do this, the method examines the soil structure, taking into account the spatial variability related to tillage and traffic (Gautronneau and Manichon, 1987; Roger-Estrade et al., 2004). This method is of great interest not only to farmers and their advisors, but also to researchers in the identification of the compartments that should be considered when studying soil properties or the impacts of soil structure on production and the environment. Examples of such uses can be found in Richard et al. (1999), Dorel et al. (2000), Neves et al. (2003), Coquet et al. (2005) and Boizard et al. (2013).

The method was developed in conventionally tilled fields, where the main drivers of change in soil structure over time are tillage and compaction. Since the 1970s, there has been a rapid increase in simplified tillage systems worldwide. In South America, North America and Australia, these tillage systems, mainly no-till (NT) or reduced tillage limited to a depth of $10 \mathrm{~cm}(\mathrm{RT})$, currently represent a significant proportion of areas of cultivation: $55 \mathrm{M}$ ha in South America, $40 \mathrm{M}$ ha in North America and $17 \mathrm{M}$ ha in Australia and New Zealand combined (Derpsch et al., 2010). In France, NT and RT have developed slowly but steadily, from 10-20\% of the wheat area in 1994 to about $40 \%$ in 2005. This proportion has remained stable, and the frequency of NT and RT systems for at least six successive growing seasons remains very low, at between 4 and $17 \%$ of crop areas (Labreuche et al., 2007; Roger-Estrade et al., 2014).

In NT and RT systems, the effects of crop residues on soil surface, soil macrofauna, root development and climatic conditions are the main drivers of change in soil structure over time, but the action of these natural factors is weak in comparison with fragmentation and compaction in conventional tillage. As the "profil cultural" method was not really designed to make an adequate assessment of these natural effects on soil structure, scientists studying conservation tillage have 
introduced new criteria. For instance, Sasal et al. (2006) and Boizard et al. (2013) propose distinguishing a platy soil structure from the $\Phi$ structure used in the "profil cultural" method (see below). Many authors have also outlined the importance of macropores due to soil biota activity in the dynamics of soil structure regeneration in reduced tillage (Capowiez et al., 2012; Piron et al., 2012; Silva et al., 2014) and developed their own system of description (Peigné et al., 2013; Piron et al., 2016 submitted). In Brazil, Tavares Filho et al. (1999) have adapted the method for no-till situations in tropical soils (such as oxisols, which are considered to have a particular behaviour).

In order to unify these various attempts to adapt the method, this paper presents a renewed approach to the "profil cultural" method resulting from a collective approach. The original method was designed to understand how the soil structure is modified by farmers under the effect of tillage and compaction. The novelty of this approach lies in its improved description of soil structure when it is altered by weathering or soil biota. The objective was to enable a more accurate diagnosis of soil structure and its consequences on production and environment in situations where there is notill, reduced tillage or localised tillage such as strip till.

This paper proposes a modified method of the "profil cultural". The initial method is outlined before the proposed improvements are presented in detail. The initial and amended methods are then compared in two situations, followed by an analysis of three experiments to identify whether the developments made to the method led to an improved soil structure assessment and thus a better diagnosis.

\section{A brief presentation of the initial "profil cultural" method}

The initial "profil cultural" method was developed by Manichon (1987) and is described in detail in Gautronneau and Manichon (1987), Peigné et al. (2013) and Roger-Estrade et al. (2004). The "profil cultural" concept was defined by Henin et al. (1969) as the part of the topsoil (i) whose structure is determined by tillage, compaction and weather conditions and (ii) where the main part 
of organic carbon, plant roots, soil biota and mineral nutrients are located. The objective of the method is to describe the structure of this part of the soil.

The description of the structure begins with a lateral and vertical partition of the cultural profile, on the face of a soil pit dug perpendicularly to the tillage direction and large enough to encompass the spatial variability of the soil structure of the field studied (Fig. 1). Different horizons are delimited by the tillage depths of the successive cultural operations and a lateral partition is determined by the location of the wheel tracks after the last ploughing, as shown in Figure 1. In a second step, each compartment is defined by the intersection of the vertical and lateral partition. Morphological units with an homogeneous soil structure are delimited in each compartment.

At this stage, an initial description of the structural organisation of the soil is produced. The degree of compaction, the spatial arrangement of clods, aggregates, voids, cracks and organic residues are described on a morphological basis. Three types of units are distinguished. Morphological units of type ' $O$ ' are highly fragmented, with the presence of small aggregates or clods. Type 'B' units are characterised by the presence of decimetric clods, produced by limited fragmentation by tillage tools (mainly the plough). In these units, voids are often observed between the clods. In type 'C' units, the soil structure is massive and clods or aggregates are not distinguishable. When large vertical cracks are present in type ' $\mathrm{C}$ ' units, the subscript ' $\mathrm{r}$ ' is added to indicate a strong swelling/shrinkage activity in the soil.

Once this is done, samples of each morphological unit are broken apart in order to characterise the soil structure at a second organisation level. The soil structure is described focusing on the type of porosity within the soil fragments that is visible to the naked eye. The specific features of each identified type are shown in Figure 2a. Type $\Delta$ is characterised by high bulk density, a high tensile strength (De Leon, 1991; Guérif et al., 1994) and altered hydraulic properties (Coutadeur et al., 2002). In type $\Delta$, structural porosity, as defined by Monnier et al. (1973), has been destroyed by severe compaction (Richard et al., 1999; Boizard et al., 2013; Sasal, 2012). Type $\Gamma$ results from the agglomeration of small soil particles under the effects of climatic conditions, biological activity and organic matter; type $\Gamma$ has a lower resistance to penetration and a higher infiltration rate than type 
$\Delta$ (de Leon, 1991; Boizard et al., 2013). $\Phi$ clods are $\Delta$ clods in which cracks have appeared due to weathering.

Finally, the two criteria (spatial arrangement of clods and type of porosity) are combined to characterise the soil structure of each morphological unit. Thus a soil structure with high structural porosity and small aggregates is characterised as $\mathrm{O} \Gamma$ and a highly compacted soil structure as $\mathrm{C} \Delta$. A ratio giving the proportion of areas with each structural type $(\mathrm{O} \Gamma, \mathrm{C} \Delta \ldots)$ can be calculated as the ratio of the area of the structural type to the total area of the horizon, as described by Boizard et al. (2013).

\section{The improved "profil cultural" method}

Since the initial method consists in a rather simple description of the effect of weathering (cracks due to shrinkage of $\Delta$ clods and the subscript " $r$ " added to morphological units of type $\mathrm{C}$ in the presence of large cracks) and does not take biological activity into account, the developments made to the method mainly focused on an improved description of these two processes. The nomenclature of the horizons and lateral positions were not modified. They remained similar to those of the initial method, except for the surface horizon. Given its importance in no-till, it was proposed that the surface horizon, including the mulch and the first centimetre of the soil under the mulch that are heavily influenced by climate and the activity of epigeic fauna, would be called HO. The description of the spatial arrangement of soil units also remained unchanged. The main changes concerned the second level of description based on the porosity, in order to take cracking and biological activity into greater account.

\section{An additional type of porosity for an enhanced description of cracking}

The clods in type $\Phi$ are composed of fragments separated by flat cracks oriented in all spatial directions (Fig. 2a). However, a special facies of porosity, characterised by a dense network of horizontal cracks, frequently appears on top of compacted volumes in situations of direct seeding or reduced tillage. This facies, called platy soil structure, has often been described in NT systems in the first ten centimetres of the topsoil in the Pampas region of Argentina (Sasal et al., 2006; 
Alvarez et al., 2009). Other authors have also reported the same facies in silty topsoils under NT in other areas (Pagliai et al., 1983; Ball and Robertson, 1994). In France, Boizard et al. (2013) revealed the development of a platy soil structure on top of compacted volumes in RT, which becomes deeper over time.

There has been limited research but nevertheless ongoing debate about the origin of this platy soil structure. Pagliai et al. (1983) attributed the striated orientation of aggregates to the effect of pressures and tensions caused by wetting and drying. Laboratory studies aiming to recreate this facies in an experiment suggested that its origin could be related to the alternation of wetting and drying cycles, inducing very high moisture gradients on top of compacted volumes (Sasal et al., 2012; Sasal et al., 2016a submitted). In terms of properties, Boizard et al. (2013) showed that shear strength decreases with platy soil structure development because horizontal cracking introduces planes of weakness, while vertical penetration resistance remains unaffected. The creation of horizontal cracks impedes vertical water transfer and thus infiltration rates in the platy soil structure, which is no different from those measured in the $\Delta$ structure. In a long-term experiment in Parana (Argentina), platy structure has been found to alter the drainage pattern, restrict water entry into the soil and favour surface runoff according to its proportion in the soil profile (Sasal et al., 2012; Sasal et al., 2016b submitted).

The importance of this process and its impact on water infiltration and rooting growth encouraged the introduction of a new type of porosity, called P, which is distinct from type $\Phi$ (Fig. 2b). Type $\Phi$ is related to the shrinkage of the clay from the drying (or freezing) of $\Delta$ clods, with the appearance of shrinkage cracks oriented in all spatial directions, individualising polyhedral aggregates, while type $\mathrm{P}$ is related to the alternation of drying and wetting cycles in the upper part of the compacted soil where drainage is slow. Although the development of the platy soil structure may be a step towards the regeneration of a $\Delta$ structure, the elongated and horizontally-oriented pores are less effective for water movement and gas exchange, and probably less effective in promoting downward proliferation of plant roots than vertically-oriented pores of the same size and shape. 
In soil, macrofauna (earthworms, ants, termites) or mesofauna (enchytraeids) perforate or ingest the soil and thus alter the soil structure. Piron et al. (2012) studied earthworm biostructures in the field to be able to describe soil structure more effectively and proposed a typology of soil-structure patterns coming from biogenic sources. The action of earthworms can involve either perforating and creating macropores, or rejecting casts (Fig. 3). Earthworms are important actors in the recovery of soil macroporosity after compaction, leading to the recovery of soil water infiltration (Capowiez et al., 2012). In the tropics, Silva et al. (2014) noted the abundant presence of macrofauna, mainly the Oligochaeta, Formicidae, Melolonthidae, Diplopoda and Chilopoda families, leading to intense biological activity with a huge number of macropores and chambers. Oliveira et al. (2012) observed that termites transform soil structure and are likely to create new microstructures and aggregates. Similarly plant roots contribute to the maintenance or modification of pore space and can penetrate compacted zones (Unger and Kaspar, 1994; Gubiani et al., 2010). It is important to consider the action of these natural agents on modifications of soil structure through the creation of a macropore network and/or the deposition of casts because these modifications play an important role in soil functioning and root access to the subsoil (Ehlers et al., 1983; McKenzie et al., 2009; Peigné et al., 2013).

Given the action of biological activity, it was proposed that the description of porosity be complemented by a criterion b (as in biology) when biological activity is identifiable in types $\Gamma, \Delta$, $\Phi$ and P. To make it easy to apply, it was decided that the criterion would only take two values: b1 for porosity facies showing the presence of tubular macropores, whatever their origin (root or fauna), and b2 when also observing fresh casts or chambers in the soil fragment, with individualised aggregates or older casts with poorly welded aggregates that could still be identified as coming from fauna (Fig. 3).

\section{Implication for the soil structure assessment on the whole profile}

In this morphological approach of soil structure, the different types of porosity of clods and aggregates are related by transformation processes in a conceptual model of soil structure dynamics (Roger-Estrade et al., 2004). A representation of the assumptions made on the processes involved 
is shown in Figure 4, where solid lines represent the processes taken into account in the initial description and dotted lines the processes added in the modified method. Severe compaction creates clods with a $\Delta$ structure, regardless of the initial structure (arrows denoted as ' 1 '). Fine aggregates (FA) are created during secondary tillage by intense fragmentation (arrows '2'). Type $\Gamma$ results from the effect of aggregation of fine soil elements (arrows ' 3 '). Type $\Phi$ results from the effect of weathering on $\Delta$ clods (arrows '4'). In the new system, type $\mathrm{P}$ is added, resulting in the transformation of $\Delta$ zones by an alternation of wetting and drying cycles in poor drainage conditions on top of compacted volumes limiting water infiltration (arrows ' 5 '). The added arrows also show the action of biological activity, modifying $\Delta, \mathrm{P}$ and $\Phi$ porosity within each type (circular arrows ' 6 ') and gradually transforms them into fine aggregates (arrows 7).

\section{Evaluation of improvements to the improved "profil cultural" method}

\subsection{Description of the five experiments}

The modified method was tested in five experiments in France (Estrées-Mons, Lyon and Kerguehennec), Argentina (Parana) and Brazil (Londrina) to evaluate the method's contribution to determining soil structure in a wide range of soils, climates and cultural practices. The situations are very different in terms of climatic conditions: annual rainfall varies between 713 and $1651 \mathrm{~mm}$ and the average temperature between 11.1 and $21{ }^{\circ} \mathrm{C}$ (Table 1). Soils are known to have very different physical behaviours. The experiments were also chosen because the experimental treatments had been set up for several years (between three and 33 years) and it was of interest to evaluate the method's ability to assess the cumulative effects of these cropping and tillage systems. On the Estrées-Mons and Parana sites, the modified method was compared to the original method, while on the three other sites, two experimental treatments were selected to identify whether the developments made to the method led to a better diagnosis of the effect of tillage systems or type of fertilisation. Soil profiles were made in 2015 at each site, except at Estrées-Mons where it was 
undertaken in 2014. The location and width of the profile were chosen to be representative of the plot, and the interpretation was undertaken qualitatively from the drawing based on the location and importance of each type of structure (Figs. 5, 6 and 7). A quantitative assessment completed the visual approach by calculating a ratio for each type of porosity as the percentage of the area to the total area of the topsoil or H5 horizon (when the H1 horizon was recently fragmented) (Table 2). As the method was very destructive and time consuming and the location of the profile was chosen to be representative of the plot, one profile was performed per plot. The percentage of areas with the presence of bioturbation within each type of structure was also calculated (Table 2).

\subsection{Comparison of the original versus the modified "profil cultural" method}

The first comparison was from the long-term experiment at Estrées-Mons in France (Boizard et al., 2013).

The treatment MONS-RT-HC under RT has high compaction risk with the late harvesting of sugar beet and maize in autumn, during wet periods of the year (Table 2). Using the initial "profil cultural" method, the high level of compaction was revealed, since $80 \%$ of the H5 horizon had a $\mathrm{C} \Delta$ or $\mathrm{C} \Phi$ soil structure (Fig. 5c). More precisely, the analysis of the structural map of the profile showed that the intensity of compaction, measured by the thickness of the compacted volume under wheel tracks, varied between cultivation operations. The analysis also provided information on the age of the compaction: it can be assumed that the $\mathrm{C} \Phi$ areas resulting from weathering of $\Delta$ zones are more aged than the $\mathrm{C} \Delta$ areas.

The same observations could be made using the modified method (Fig. 5d). Using the improved method, an intense biological activity was observed throughout the $\mathrm{C} \Gamma$ areas, with the presence of tubular pores and casts. The modified method also allowed a differentiation to be made within the highly compacted areas according to earthworm activity: about $85 \%$ of $(C \Phi+C \Delta)$ areas were colonised by earthworms that created macropores (Table 2); the zones with no macropores were located at the top of the horizon and probably resulted from more recent compaction performed after the earthworm action, destroying the biopores. The modified method also allowed a CP 
structure to be identified at the top of the C $\Phi$ zones: it could be assumed that the platy soil structure resulted from reduced drainage during wet periods at the top of ancient $\mathrm{C} \Delta$ volumes, which were then transformed into $\mathrm{C} \Phi$ structure by weathering. In the cases where no $\mathrm{CP}$ structures were present above $\mathrm{C} \Delta \mathrm{b} 1$ volumes, it could be assumed that recent compaction had destroyed the soil structure.

Furthermore, the new method gave a more precise analysis of the effect of soil structure on root growth. Indeed, with the initial method (Fig. 5c), it was assumed that all the $\mathrm{C} \Delta$ volumes within the soil profile severely impeded rooting (about $50 \%$ of the volume of the horizon), while the $\mathrm{C} \Gamma$ and CФ zones were favourable. The analysis was different with the modified method (Fig. 5d): roots could colonise the $\mathrm{C} \Delta \mathrm{b} 1$ units as well as the $\mathrm{C} \Phi \mathrm{b} 1$ ones. Therefore, the remaining unfavourable zones $(\mathrm{C} \Delta$ and $\mathrm{CP})$ represented less than $20 \%$ of the volume of the horizon. This observation was consistent with many results showing a similar yield in NT and CT treatments. Similarly, the modified method allowed a better prediction of the soil structure's effects on the water regime which was deemed to be more favourable with the new method, because the presence of macropores plays a major role in the restoration of infiltration rate following compaction.

The second comparison was from Parana in Argentina in no-till and continuous soybean (PAR-NTCS) for seven years. From the assessment using the initial method, $85 \%$ of the H5 horizon was identified as $c \Phi$, resulting from compaction followed by cracking under the effect of climate. Some $\mathrm{C} \Delta$ volumes were observed within the $\mathrm{H} 5$ horizon, probably resulting from more recent compaction (Fig. 6c). The modified method gave a more precise description of the structure, with the presence of a continuous platy soil structure in the upper part of the soil profile and a massive structure with the presence of vertical cracks and tubular macropores in the bottom part of the H5 horizon, (Fig. $6 \mathrm{~d}$ and Table 2). It was also observed that part of the $\mathrm{C} \Delta$ volumes exhibited macropores, due to root development $(\mathrm{C} \Delta \mathrm{b} 1)$. In this situation, the continuous platy soil structure over the entire width of the profile is an obstacle to rooting and water infiltration, favouring runoff, while the continuous $\mathrm{C} \Phi \mathrm{b} 1$ soil structure below (with vertical cracks and macropores created by the roots of previous 
crops) favours rooting. In the same experiment in Parana, PAR-NT-CS with the continuous soybean was compared to a crop succession under no-till: wheat/soybean-maize rotation (PAR-NTR). Observation of the soil structure with the modified method showed that the platy soil structure in PAR-NT-R was $45 \%$ thinner and the mulch 50\% thicker than in PAR-NT-C, while the two soil profiles were similar to the initial method. The modified method gave a more precise description of the structure, which was more consistent with the intensity of runoff and erosion and the observations of the root system, as shown by Sasal et al. (2016b submitted).

\subsection{Application of the improved "profil cultural" method}

The improved method was tested in three others sites. to identify whether the developments made to the method led to an improved soil structure assessment and thus a better diagnosis.

\section{Comparison of organic and mineral fertilisation under no-till}

At Kerguehennec in western France, mineral versus poultry manure fertilisation was compared for 15 years on a maize/winter wheat/rape/winter wheat crop rotation and phacelia (cover crop) in a Humic Cambisol (Table 1). The treatment with mineral fertilisation (KER-NT-M) exhibited a continuous soil structure in $\mathrm{H} 5$, that was highly porous $(\mathrm{C} \Gamma \mathrm{b} 2)$, with biological porosity resulting from earthworm activity (Fig. 7). In contrast, compacted volumes were identified in KER-NT-P, with large $c \Delta b 1$ volumes and platy soil structures $(\mathrm{CP})$. Compaction resulted from the spreading of manure in wet conditions. In KER-NT-P, analysis of the $\mathrm{C} \Delta \mathrm{b} 1$ units allowed not only an evaluation of the compaction due to manure spreading (which was already the case with the former method), but also (i) the study of the influence of earthworms on soil structure regeneration and (ii) the dynamics of platy soil structure development in the poorly drained zones of the profile. In KERNT-M, the modified method did not improve the diagnosis of soil structure compared to the initial method. 
In Londrina in Brazil, no-till (LOND-NT) versus conventional tillage with disc ploughing (LONDCTD) was compared for 33 years on a soybean/wheat crop rotation in an Oxisol. Compaction was observed in the two experimental treatments, with $\mathrm{C} \Delta$ soil structure dominant in $\mathrm{H} 5$ (Fig. 7 and Table 2). In LOND-NT, the origin of the compaction in $\mathrm{C} \Delta \mathrm{b} 1$ zones could be attributed to wheel tracks at harvesting. However, analysis of the other compacted volumes in LOND-NT and LONDCTD did not allow a conclusion to be drawn between compaction by wheels or hard setting. The main difference between the two experimental treatments was the spatial arrangement of the soil structure. In LOND-CTD, a clear distinction between the different layers was observed in H5. From the bottom to the mulch at the surface, there was a severely compacted horizon without any trace of biological activity, then a compacted layer with biological pores, topped by a compacted layer with biopores and cracks due to weathering. The structure in LOND-NT appeared to be more homogenous with a high presence of biological pores and casts on the whole soil profile. In Londrina, the modified method allowed a more precise analysis of the effect of soil biota on structure, in interaction with the compaction process due to wheeling or climate (hard setting).

In Lyon in France, ploughed (LYON-CT) and no tilled (LYON-NT) systems were compared for three years on a winter wheat/maize/soybean crop rotation in a Fluvisol. In LYON-NT, a significant proportion of the $\mathrm{H} 5$ horizon was highly compacted due to repeated passages of wheels in moist conditions in 2013 and 2014. However, the significant presence of biological activity (b1) had the ability to reduce the effect of this compaction on rooting and water infiltration as well as climate (shrinkage had created a $\mathrm{Cr} \Delta$ zone in the centre of the $\mathrm{H} 5$ horizon). The climate also induced CP soil structure in this poorly drained soil profile, which was already visible after just three years of no-till. As in Londrina, a continuous mulch of residues mixed with a fragmentary and fine soil structure was observed on the soil surface under no-till.

In LYON-CT, the soil structure was more favourable in the ploughed horizon (H5), with dominant ОГ soil structure resulting from fragmentation by the tools. However an H6 horizon $(25-40 \mathrm{~cm}$ depth) presented severe compaction, with only some earthworm galleries likely to ensure the 
passage of roots and water. In the Lyon experiment, the modified method revealed that biological activity was fairly efficient at regenerating a compacted structure in the no till treatment, while it was not very efficient in the LYON-CT profile, for which the H6 horizon remained an obstacle for root growth and water infiltration.

\section{Discussion}

\section{Benefits of the improved method for enhanced understanding of the impacts of cropping systems}

The results obtained from the comparison of the initial and modified method at Estrées-Mons and Parana showed that the modified method allowed a more precise characterisation of the effects of natural processes on soil structure dynamics, and thus a better prediction of its consequences on plant growth and hydric properties. The application of the improved method in the other three sites highlighted differences in soil structure between the treatments, irrespective of the experiment. Both the initial and the modified method revealed changes in soil structure over time due to compaction, but the modified method enabled differences in soil structure altered by natural processes to be observed more precisely. Bioturbation was higher in no-till treatments (compared to conventional tillage systems) and could be zero in the deep horizons of conventional systems, which is consistent with many studies (Tebrügge and Düring, 1999; Jossi et al., 2011; Crittenden et $a l ., 2015)$. Similarly, the ability to distinguish between the platy soil structure and other types of cracking improved the interpretation of the consequences of soil structure: although they are porous, root growth and infiltration are impeded in such structures.

\section{Added value of the changes for users}

Consultants and advisors primarily use the "profil cultural" method to make diagnoses in field conditions and help farmers make decisions. The issues involved may differ, such as the choice of equipment to limit soil compaction, as in Kerguehennec, or the effect of tillage system on plant development, as in Londrina and Lyon. The modified method resulted in a more accurate diagnosis. An example of its use can be taken from a recent study conducted on a potato crop in an area of intensive agriculture in northern France. Using the modified method, Tomis et al. (2013) 
showed that the rooting depth of the potato crop in deeply compacted soils was dependent on the presence of macropores: rooting is limited to $30-40 \mathrm{~cm}$ in the absence of macropores and can reach $80 \mathrm{~cm}$ in the presence of vertical macropores created by anecic earthworms. This example shows that the diagnosis of the effect of this soil structure on rooting could be more severe if the presence of biopores is not taken into account. Furthermore, this method offers a framework to study the effects of natural agents on the regeneration of degraded structures in field conditions. The comparison of zones with different ages of the compaction event allows an appreciation of the speed and intensity of this natural regeneration process. Sasal et al. (2016b, submitted) also highlight the need to properly describe the features related to the action of natural processes for a better diagnosis of the runoff and erosion risks. In the context of the research, there are several objectives in using the "profil cultural" method, for instance to identify the spatial variability of soil structure in order to improve the sampling strategy for the study of soil properties or soil-root relationships (Neves et al., 2003), to acquire a better understanding of soil structure dynamics (Sasal et al., 2012; Boizard et al., 2013) or to study soil biota (Vian et al., 2009). This is particularly important in the context of tillage systems taking agroecology into consideration, where biological activity plays an important role.

\section{Issues}

Nevertheless several issues emerged that require further research. Knowledge about bioturbation is fragmentary: although the activity of earthworms is well known from numerous studies, less is known about the action of other species. This is the case with intense biological activity, particularly in the tropics where many species of different sizes are involved and little is known about their effect on structure. With regard to the action of earthworms, Capowiez et al. (2012) have shown that soil structural porosity and associated properties remain very low in compacted zones for several years, despite the significant and rapid contribution of earthworms to the infiltration rate by creating macropores. However these results are partial and there is a need for more research to understand how porosity and physical and hydraulic properties are altered by different types of species and bioturbation. 
Another point about the implementation of the "profil cultural" method is that in this study its implementation was observed by experts who have many years' experience. Thirteen users of the method were surveyed about the changes introduced in France and Argentina. All the experts considered that these amendments were necessary and would be useful in improving their diagnosis in the field by integrating the role of roots and soil fauna in soil functioning. However several of them suggested that it would be difficult to implement this method in no-till since a level of expertise is required to evaluate the different criteria and would necessitate training in using the improved method correctly. Consideration should be given to organising training sessions and publishing a step-by-step guide for users. Interest was also expressed in a guide incorporating several methods and taking the soil and subsoil into account, as proposed by Batey et al. (2015).

\section{Conclusions}

Improvements to the "profil cultural" method were proposed from a collective approach and the method tested in five experimental situations in 2014 and 2015. The results demonstrated the modified method's ability to highlight differences in soil structure, make assumptions about their origin, whether they were caused by cultural operations, tillage systems soil or crop sequences, and predict consequences on the crop and the environment. This modified method should enable consultants and advisors to make more accurate diagnoses and allow scientists to give greater consideration to natural processes in field research.

\section{Acknowledgments}

This work was conducted with financial support from ISTRO and INRA, who supported the coordination meeting in Lyon, and from the French National Research Agency (ANR) through the SOFIA research project (SOil Functional diversity as an Indicator of sustainable management of Agroecosystems). The authors are grateful to ISARA Lyon, the Chambre Régionale d'Agriculture de Bretagne, the experimental domain of INRA at Estrées-Mons, INTA EEA Parana, and Embrapa 
Soja at Londrina who have maintained the long-term experiments. The authors are grateful to Jérôme Labreuche (Arvalis), Rémi Koller (ARAA), Jacques Caneill (ENESAD), Jean-Pascal Mure (Chambre d'agriculture de l'Isère), Olivier Chrétien, Gilles Sauzet (Terra Inovia), Olivier Ancelin (Chambre d'agriculture de la Somme), Yvan Capowiez (INRA - PSH), Guillermo Gerster and Silvina Bacigaluppo (INTA Oliveros), Javier Elisei and Manuel Ferrari (INTA Pergamino) and Emmanuel Gabioud (INTA Paraná) who responded to the survey on the evolution of the method. The English text was edited by Claire Tarring. 


\section{References}

Alvarez, R., Steinbach, H.S., 2009. A review of the effects of tillage systems on some soil physical properties, water content, nitrate availability and crops yield in the Argentine Pampas. Soil \& Tillage Research, 104, 1-15.

Ball, B.C., Robertson, E.A.G., 1994. Effects of soil water hysteresis and the direction of sampling on aeration and pore function in relation to soil compaction and tillage. Soil Tillage Research, 32, 51-60.

Batey, T., Guimaräes, M.L., Peigné, J., Boizard, H., 2015. Assessing structural quality for crop performance and for agronomy (VESS, VSA, SoilPak, Profil cultural, SubVESS. In: Visual Soil Evaluation: Realizing Potential Crop Production with Minimum Environmental Impact (Ball, B.C., Munkholm L.J. Eds CAB international), 2: 15-30.

Boizard, H., Batey, T., McKenzie, D., Richard, G., Roger-Estrade, J., Ball, B. C., Bradley, I., Cattle, S., Hasinger, G., Munkholm, L., Murphy, B. W., Nievergelt, J., Peigné, J., Shepherd, G., 2005. Field meeting "visual soil structure assessment" held at the INRA, Research Station, Estrées Mons, France, 642 25-27 May 2005. Detailed report, http:/ http://iworx5.webxtra.net/ istroorg/download/WG Visual Soil Structure Assessment_Field meeting.pdf

Boizard, H., Yoon, S.W., Léonard, J., Lheureux, S., Cousin, I., Roger-Estrade, J., Richard, G., 2013. Using a morphological approach to evaluate the effect of traffic and weather conditions on the structure of a loamy soil in reduced tillage. Soil \& Tillage Research, 127, 34-44.

Capowiez, Y., Samartino, S., Cadoux, S., Bouchant, P., Richard, G., Boizard, H., 2012. Role of earthworms in regenerating soil structure after compaction in reduced tillage systems. Soil Biology and Biochemistry, 55, 93-103.

Coquet, Y., Coutadeur, C., Labat, C., Vachier, P., Roger-Estrade, J., Simunek, J., 2005. How do tillage practices affect water and solute transport? 1. A field experiment. Vadose Zone Journal, 4, 573-586.

Coutadeur, C., Coquet, Y., Roger-Estrade, J., 2002. Variation of hydraulic conductivity in a tilled soil. European Journal of Soil Science, 5:43, 619-628

Crittenden, S. J., Poot, N., Heinen, M., van Balen, D., Pulleman, M. M., 2015. Soil physical quality in contrasting tillage systems in organic and conventional farming. Soil \& Tillage Research, 154, 136-144

De Leon, F., 1991. Morphologie, propriétés physiques et conditions de formation des éléments structuraux de la couche labourée. Thèse. Institut National Agronomique Paris-Grignon, Paris.

Derpsch, R., Friedrich, T., Kassam, A., Hongwen, L., 2010. Current status of adoption of no-till farming in the world and some of its main benefits. Int. J. Agric. \& Biol. Eng., 3-1, 1-26. Open Access at http://www.ijabe.org

Dorel, M., Roger-Estrade, J., Manichon, H., Delvaux, B., 2000. Porosity and soil water properties of Caribbean volcanic ash soils. Soil Use and Management, 16, 133-140

Ehlers, W., Kopfe, U., Hesse, F., Böhm, W., 1983. Penetration resistance and root growth of oats in tilled and untilled loess soil. Soil \& Tillage Research, 3, 261--275

Gautronneau, Y., Manichon H. 1987. Guide méthodique du profil cultural. CEREF-ISARA/GEARA-INAPG. http://profilcultural.isara.fr/

Gregorutti, V.C., Novelli, L.E., Melchiori, R.J.M., Ormaechea, M.V., Caviglia, O.P., 2014. Nitrógeno incubado en anaerobiosis y su relación con el nitrógeno orgánico en diferentes fracciones. Ciencia Del Suelo, 32:1, 41-51.

Gubiani, P. I., Reichert, J. M., Reinert, D. J., Gelain, N. S., 2010. Soil resistance to penetration under the dynamic and predictive perspective of restriction to crop yield. Pages 161-164 in Proceedings of 19th World Congress of Soil Science, Soil Solutions for a Changing World.

Guérif, J., De Leon Gonzales, F., Stengel, P., 1994. Variability of internal structure of clods in relation to soil conditions prior compaction, effect on soil strength. In: Jensen, H.E., Schjonning,P., Mikkelsen, S.A., Madsen, K.B. (Eds.), Proceedings 13th international ISTRO conference Soil Tillage for Crop Production and Protection of the Environment, 24-29 July, 1994, Aalborg, 1, 543-548.

Henin, S., Gras, R., Monnier, G., 1969. Le profil cultural (2e édition) - Masson Ed. Paris 
Jossi, W., Zihlmann, U., Anken, T., Dorn, B., Van der Heijden, M, Tschachtli, R., 2011. Reduced tillage protects earthworms. Soil \& Tillage Research, 2, 432-439

Labreuche, J., Le Souder, C., Castillon, P., Ouvrey, J. F., Réal, B., Germon, J. C., De Tourdonnet, S., 2007. Evaluation des impacts environnementaux des Techniques Culturales Sans Labour (TCSL) en France (Assessment of the environmental impact of non-inversion tillage methods in France). ADEME-ARVALIS Institut du végétal-INRAAPCA-AREAS-ITB-CETIOM- IFVV.

McKenzie, B.M., Bengough, A.G., Hallett, P.D, Thomas, W.T.B., Forster, B., McNicol, J.W., 2009. Deep rooting and drought screening of cereal crops: A novel field-based method and its application. Field Crops Research. 112, 165171.

Manichon, H., 1987. Observation morphologique de l'état structural et mise en évidence d'effets de compactage des horizons travaillés. In: Monnier, G., Goss, M.J. (Eds.), Soil Compaction and Regeneration. Balkema, Rotterdam, the Netherlands, 39-52.

Monnier, G., Stengel, P., Fies, J.C., 1973. Une méthode de mesure de densité apparente de petits agglomérats terreux. Application a` l'analyse des systèmes de porosité du sol. Annales Agronomiques 24, 533-545.

Neves, C. S. V. J., Feller, C., Guimarães, M. F., Medina, C. C., Tavares Filho, J., Fortier, M., 2003. Soil bulk density and porosity of homogeneous morphological units identified by the Cropping Profile Method in clayey Oxisols in Brazil. Soil \& Tillage Research, 2, 109-119.

Novelli, L.E., 2013. Intensificación de las secuencias de cultivos en un Molisol y un Vertisol: cambios en la estabilidad estructural y en el almacenaje de $\mathrm{C}$ en agregados. Tesis Doctoral. EPG-FAUBA

Oliveira, M.I.L., Benito, N. P., Camargo, A. J. A., Guimarães, M. F., Brossard M., 2012. Atividade de colônias de Cornitermes Cumulans (Isoptera, Nasutitermitinae) sobre estruturas edáficas macro e microagregadas em casa de vegetação. Semina. Ciências Agrárias (Online), 33, 1733-1744,

Pagliai, M., LaMarca, M., Lucamante, G.. 1983. Micromorphometric and micromorphological investigations of a clay loam soil in vitiviniculture under zero and conventional tillage. Journal Soil Science, 34, 391-403.

Peigné, J., Vian, JF., Cannavaciuolo, M., Lefevre, V., Gautronneau, Y., Boizard H., 2013. Assessment of soil structure in the transition layer between topsoil and subsoil using the profil cultural method. Soil and Tillage Research, 127: 1325 .

Piron, D., Pérès G., Hallaire, V., Cluzeau, D., 2012. Morphological description of soil structure patterns produced by earthworm bioturbation at the profile scale. European Journal of Soil Biology, 50, 83-90

Piron, D., Boizard, H., Heddadj, D., Pérès G., Hallaire, V., Cluzeau, D., 2016. Indicators of earthworm bioturbation for improving visual assessment of soil structure. Submitted to Special Issue: VSE and Compaction Res. of Soil \& Tillage Research

Richard G., Boizard H., Roger-Estrade J., Boiffin J., Guérif J., 1999. Field study of soil compaction due to traffic: pore space and morphological analysis. Soil \& Tillage Research, 51, 151-160.

Roger-Estrade, J., Richard, G., Caneill, J., Boizard, H., Coquet, Y., Defossez, P., Manichon, H., 2004. Morphological characterization of soil structure in tilled fields: from a diagnosis method to the modeling of structural changes over time. Soil \& Tillage Research 79, 33-49.

Roger-Estrade J., Labreuche J., Boizard H., 2014. Importance du travail du sol : typologie des modes de mise en œuvre et effets sur le rendement des cultures. In : Faut-il travailler le sol ? Acquis et innovation pour une agriculture durable. (J. Labreuche, F. Laurent, J. Roger-Estrade, coord.), chapitre 3, collection Savoir-faire, éditions Quæ, Versailles, 11-25.

Sasal, M.C., Andriulo, A.E., Taboada, M.A., 2006. Soil porosity characteristics and water movement under zero tillage in silty soils in Argentinian Pampas. Soil \& Tillage Research, 87, 9-18

Sasal, M.C., 2012. Factores condicionantes de la evolución estructural de suelos limosos bajo siembra directa. Efecto sobre el balance de agua. Doctoral Thesis. Escuela para Graduados Alberto Soriano, Universidad de Buenos Aires. 
Sasal, M.C., Léonard, J., Andriulo, A., Boizard, H., 2016a. A contribution to understanding the origin of soil platy structure in no tillage. Submitted to Special Issue: VSE and Compaction Res. of Soil \& Tillage Research

Sasal, M.C., Boizard, H., Andriulo, A., Wilson, M., Léonard, J., 2016b. Platy structure development under No-tillage in the northern humid pampas of Argentina and its impact on runoff. Submitted to Special Issue: VSE and Compaction Res. of Soil \& Tillage Research

Silva, A. P., Babujia, L. C., Franchini, J. C., Ralisch, R., Hungria, M., Guimarães, M. F., 2014. Soil structure and its influence on microbial biomass in different soil and crop management systems. Soil \& Tillage Research, 142, 42-53

Tavares Filho, J., Ralisch, R., Guimarães, M.F., Medina, C.C., Balbino, L.C., Neves, C.S.V.J., 1999. Metodo do perfil cultural para avaliaçao do estado fisico de solos em condiçoes tropicais. R. Bras. Ci. Solo, 23:393-399

Tebrügge, F., Düring, R..A., 1999. Reducing tillage intensity: a review of results from a long-term study in Germany. Soil \& Tillage Research 53, 15-28

Tomis, V., Martin, M., Duparque, A., Boizard, H., 2015. Pomme de terre, une culture sensible aux tassements du sol. Perspectives agricoles, 419, février 2015

Unger, W. and Kaspar, T., 1994. Soil Compaction and Root Growth: A Review. Agronomy Journal, 86, 759-766.

Vian J.F., Peigné J., Chaussod R., Roger-Estrade J., 2009. Effects of four tillage systems on soil structure and soil microbial biomass in organic farming. Soil Use and Management, 25, 1-10. 


\section{Tables}

Table 1. Main characteristic of topsoil on the experimental sites.

\begin{tabular}{|c|c|c|c|c|c|c|c|c|c|c|c|c|c|c|c|c|}
\hline $\begin{array}{l}\text { Experiment } \\
\text { al site }\end{array}$ & $\begin{array}{l}\text { Objective of the long } \\
\text { term experiment }\end{array}$ & Location & References & Soil type & $\begin{array}{l}\text { Clay } \\
\mathrm{g} \mathrm{g}^{-1}\end{array}$ & $\begin{array}{l}\text { Silt } \\
\mathrm{g} \mathrm{g}^{-1}\end{array}$ & $\begin{array}{l}\text { Sand } \\
\mathrm{g} \mathrm{g}^{-}\end{array}$ & $\begin{array}{l}\mathrm{C} \\
\%\end{array}$ & $\mathrm{pH}$ & $\begin{array}{l}\text { Annual } \\
\text { rainfall } \\
(\mathrm{mm})\end{array}$ & $\begin{array}{l}\text { Average } \\
\text { annual } \\
\text { air } \\
\text { temperat } \\
\text { ure }\left({ }^{\circ} \mathrm{C}\right)\end{array}$ & $\begin{array}{l}\text { Crop at the time } \\
\text { of assessment }\end{array}$ & $\begin{array}{l}\text { Duration } \\
\text { of the } \\
\text { experime } \\
\text { nt (year) }\end{array}$ & $\begin{array}{l}\text { Date of } \\
\text { assessme } \\
\text { nt }\end{array}$ & $\begin{array}{l}\text { Soil water } \\
\text { content at } \\
\text { the time } \\
\text { of } \\
\text { assessing } \\
\text { (g g-1) }\end{array}$ & Operators \\
\hline $\begin{array}{l}\text { France - } \\
\text { Estrées } \\
\text { Mons }\end{array}$ & $\begin{array}{l}\text { Influence of compaction } \\
\text { risk and soil tillage } \\
\text { system on soil structure } \\
\text { dynamics }\end{array}$ & $\begin{array}{l}50^{\circ} \mathrm{N} \\
3^{\circ} \mathrm{E} \\
85 \mathrm{~m} \\
\text { elevation }\end{array}$ & $\begin{array}{l}\text { Boizard et } \\
\text { al., } 2013\end{array}$ & $\begin{array}{l}\text { Haplic } \\
\text { luvisol }\end{array}$ & 0.19 & 0.76 & 0.05 & 0.9 & $\begin{array}{l}7.6 \\
\mathrm{H}_{2} \mathrm{O}\end{array}$ & 713 & 11.1 & $\begin{array}{l}\text { winter wheat } \\
\text { ( Triticum } \\
\text { aestivum) }\end{array}$ & 16 & $\begin{array}{l}\text { April } \\
2014\end{array}$ & 22 & $\begin{array}{l}\text { Hubert Boizard } \\
\text { and Denis Piron }\end{array}$ \\
\hline $\begin{array}{l}\text { Argentina - } \\
\text { Parana }\end{array}$ & $\begin{array}{l}\text { Effect of crop sequence } \\
\text { on soil structure } \\
\text { dynamics under no } \\
\text { tillage }\end{array}$ & $\begin{array}{l}31^{\circ} \mathrm{S} \\
60^{\circ} \mathrm{W} \\
95 \mathrm{~m} \\
\text { elevation }\end{array}$ & $\begin{array}{l}\text { Gregorutti } \\
\text { et al., } 2014 \\
\text { Novelli et } \\
\text { al., } 2013\end{array}$ & $\begin{array}{l}\text { Aquic } \\
\text { Argiudoll }\end{array}$ & 0.27 & 0.67 & 0.06 & 1.5 & $\begin{array}{l}6.9 \\
\mathrm{H}_{2} \mathrm{O}\end{array}$ & 1030 & 18 & $\begin{array}{l}\text { Soybean } \\
\text { residues } \\
\text { (Glycine max) }\end{array}$ & 7 & $\begin{array}{l}\text { June } \\
2015\end{array}$ & 23.7 & $\begin{array}{l}\text { Carolina Sasal } \\
\text { and Juan José } \\
\text { De Battista }\end{array}$ \\
\hline $\begin{array}{l}\text { France - } \\
\text { Kerguehen } \\
\text { nec }\end{array}$ & $\begin{array}{l}\text { Influence of soil tillage } \\
\text { systems with different } \\
\text { types of fertilisation on } \\
\text { soil functioning }\end{array}$ & $\begin{array}{l}47^{\circ} \mathrm{N} \\
2^{\circ} \mathrm{W} \\
112 \mathrm{~m} \\
\text { elevation }\end{array}$ & $\begin{array}{l}\text { Piron et al., } \\
2012\end{array}$ & $\begin{array}{l}\text { Humic } \\
\text { Cambisol }\end{array}$ & 0.16 & 0.43 & 0.41 & 2.1 & $\begin{array}{l}6.4 \\
\mathrm{H}_{2} \mathrm{O}\end{array}$ & 957 & 11.6 & $\begin{array}{l}\text { Phacelia } \\
\text { ( Phacelia } \\
\text { tanacetifolia) }\end{array}$ & 15 & $\begin{array}{l}\text { October } \\
2015\end{array}$ & 16 & $\begin{array}{l}\text { Jubert Boizard, } \\
\text { Denis Piron and } \\
\text { Djilali Heddadj }\end{array}$ \\
\hline $\begin{array}{l}\text { Brazil - } \\
\text { Londrina }\end{array}$ & $\begin{array}{l}\text { Comparison of no till } \\
\text { and plough tillage } \\
\text { systems on a soybean- } \\
\text { wheat crop rotation }\end{array}$ & $\begin{array}{l}23^{\circ} \mathrm{S} \\
51^{\circ} \mathrm{W} \\
585 \mathrm{~m} \\
\text { elevation }\end{array}$ & $\begin{array}{l}\text { No } \\
\text { scientific } \\
\text { publication }\end{array}$ & $\begin{array}{l}\text { Rhodic } \\
\text { Eutrudox }\end{array}$ & 0.83 & 0.11 & 0.06 & 1.5 & $\begin{array}{l}5.2 \\
\mathrm{CaCl} \\
2\end{array}$ & 1651 & 21 & $\begin{array}{l}\text { Wheat } \\
\text { ( Triticum } \\
\text { aestivum) }\end{array}$ & 33 & $\begin{array}{l}\text { July } \\
2015\end{array}$ & $\begin{array}{l}\text { Field } \\
\text { capacity }\end{array}$ & $\begin{array}{l}\text { Ricardo Ralisch, } \\
\text { Carolina Sasal, } \\
\text { Julio Franchini } \\
\text { and Fátima } \\
\text { Guimarães }\end{array}$ \\
\hline $\begin{array}{l}\text { France - } \\
\text { Lyon }\end{array}$ & $\begin{array}{l}\text { Comparison of no till } \\
\text { and plough tillage } \\
\text { systems on maize- } \\
\text { soybean-winter wheat } \\
\text { crop rotation }\end{array}$ & $\begin{array}{l}45^{\circ} \mathrm{N} \\
4^{\circ} \mathrm{E} \\
204 \mathrm{~m} \\
\text { elevation }\end{array}$ & $\begin{array}{l}\text { No } \\
\text { scientific } \\
\text { publication }\end{array}$ & Fluvisol & 0.11 & 0.59 & 0.30 & $\begin{array}{l}0.8 \\
8\end{array}$ & $\begin{array}{l}7.1 \\
\mathrm{H}_{2} \mathrm{O}\end{array}$ & 860 & 11.4 & $\begin{array}{l}\text { Crop residues / } \\
\text { bare soil }\end{array}$ & 3 & $\begin{array}{l}\text { March } \\
2015\end{array}$ & 21.7 & $\begin{array}{l}\text { Joséphine } \\
\text { Peigné and Jean- } \\
\text { François Vian }\end{array}$ \\
\hline
\end{tabular}


Table 2. Quantitative assessment of soil structure in the five experiments. The percentage of each type of porosity was calculated as the area of the type of porosity to the total area of the observed horizons using the improved method. The figures in brackets give the percentage of areas with presence of bioturbation within each type of structure

\begin{tabular}{|c|c|c|c|c|c|c|c|}
\hline Site & Rotation & $\begin{array}{l}\text { Experimental } \\
\text { treatment }\end{array}$ & Description of the treatment & $\% \Gamma$ & $\% \Delta$ & $\% \Phi$ & $\% \mathrm{P}$ \\
\hline $\begin{array}{l}\text { F - } \\
\text { Estrées } \\
\text { Mons }\end{array}$ & $\begin{array}{l}\text { Sugar beet/winter wheat/maize/winter wheat } \\
\text { (Beta vulgaris } L / \text { Triticum aestivum/Zea mays L./ } \\
\text { Triticum aestivum) }\end{array}$ & $\begin{array}{l}\text { MONS-RT- } \\
\text { HC }\end{array}$ & $\begin{array}{l}\text { Rotation having high compaction } \\
\text { risk in reduced tillage }(<6 \mathrm{~cm} \\
\text { depth) }\end{array}$ & $20(100)$ & $48(80)$ & $27(100)$ & $5(100)$ \\
\hline \multirow[t]{2}{*}{ A-Parana } & $\begin{array}{l}\text { Continuous soybean } \\
\text { (Glycine } \max L . \text {.) }\end{array}$ & PAR-NT- CS & No till with continuous soybean & $8(0)$ & $14(20)$ & $41(100)$ & $37(0)$ \\
\hline & $\begin{array}{l}\text { Maïs/blé-soybean } \\
\text { (Zea mays L.- Triticum aestivum/Glycine max L.) }\end{array}$ & PAR-NT-R & No till with crop rotation & $16(100)$ & $14(0)$ & $46(100)$ & $24(0)$ \\
\hline \multirow{2}{*}{$\begin{array}{l}\text { F- } \\
\text { Kerguehe } \\
\text { nnec }\end{array}$} & $\begin{array}{l}\text { Maize/winter wheat/rape /winter wheat and } \\
\text { phacelia (cover crop) }\end{array}$ & KER-NT-M & No till with mineral fertilisation & $94(100)$ & $6(100)$ & & \\
\hline & $\begin{array}{l}\text { (Zea mays L./ Triticum aestivum/ Brassica napus } \\
\text { L./Triticum aestivum and Phacelia tanacetifolia) }\end{array}$ & KER-NT-P & No till with poultry manure & $73(100)$ & $19(100)$ & & $8(0)$ \\
\hline \multirow{2}{*}{$\begin{array}{l}\text { B- } \\
\text { Londrina }\end{array}$} & Soybean/wheat & LOND-NT & No-till & $17(100)$ & $80(100)$ & & $3(0)$ \\
\hline & Glycine max L./ Triticum aestivum & LOND-CTD & $\begin{array}{l}\text { Conventional tillage with disc } \\
\text { ploughing }\end{array}$ & $19(100)$ & $81(52)$ & & \\
\hline \multirow[t]{2}{*}{ F-Lyon } & winter wheat/maize/soybean & LYON-NT & No-till & $17(100)$ & $68(58)$ & & $15(0)$ \\
\hline & (Triticum aestivum/Zea mays L./ Glycine max L.) & LYON-CT & $\begin{array}{l}\text { Conventional tillage with } \\
\text { mouldboard ploughing }\end{array}$ & $44(100)$ & $56(52)$ & & \\
\hline
\end{tabular}




\section{Figures}

Figure 1. Principle of the stratification of the observation face of a soil pit from an example in plough tillage system. Vertical partition: $\mathrm{H} 1$ to $\mathrm{H} 4=$ secondary tillage operations, $\mathrm{H} 5=$ primary tilled horizon not affected by secondary tillage, $\mathrm{H} 6$ and $\mathrm{H} 7$ = older tilled horizons when ploughing was deeper and $\mathrm{P} 1=$ pedological layer, called $\mathrm{H} 8$ if it is affected by tillage (subsoiling) $\mathrm{H} 1=$ secondary tillage; $\mathrm{H} 5$ primary tilled horizon not affected by secondary tillage; $\mathrm{H} 6=$ older tilled horizons and P1 = pedological horizon. Lateral partition: L1 part of the profile located under the wheel tracks of field operation(s) done after secondary tillage, L2 part of the profile located under the wheel tracks that is not visible on the soil surface, generally created during secondary tillage and L3 part unaffected by the wheels since the last ploughing. Morphological units (U1, U2...) have a homogeneous soil structure.

Figure 2a. Morphological aspect of the three types of porosity in the initial method. The samples were observed in a silty loam at Estrées-Mons (Northern France)

Figure 2b. Morphological aspect of the type of porosity $\mathrm{P}$, which supplemented the three original types. The sample was also observed in the silty loam at Estrées-Mons (Northern France)

Figure 3. The biological indicator illustrated for both b1 and b2 and for different types of porosity with the improved method

Figure 4. Changes in structural porosity over time. FA is fine aggregates. The initial model is shown by solid lines. The amendments proposed in the modified model are shown by dotted lines

Figure 5. Cultural profiles observed on a $240 \mathrm{~cm}$-wide profile in Estrées-Mons: picture of the profile (4a); zoom on some structural states (4b); drawing using the initial method (4c); drawing using the modified method (4d). Structural state are: (—) $\mathrm{C} \Delta$; ( 8 bioturbation is indicated on each unit

Figure 6. Cultural profiles observed on a $160 \mathrm{~cm}$-wide profile in Parana: picture of the profile (4a); zoom on some structural states (4b); drawing using the initial method (4c); drawing using the modified method (4d). Structural state are: (—) C $\Delta$; ( bioturbation is indicated on each unit

Figure 7. Drawing of the cultural profiles observed with the modified method in Kerguehennec,

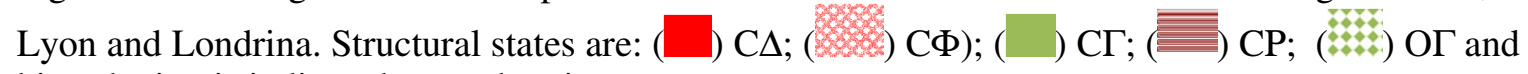
bioturbation is indicated on each unit 


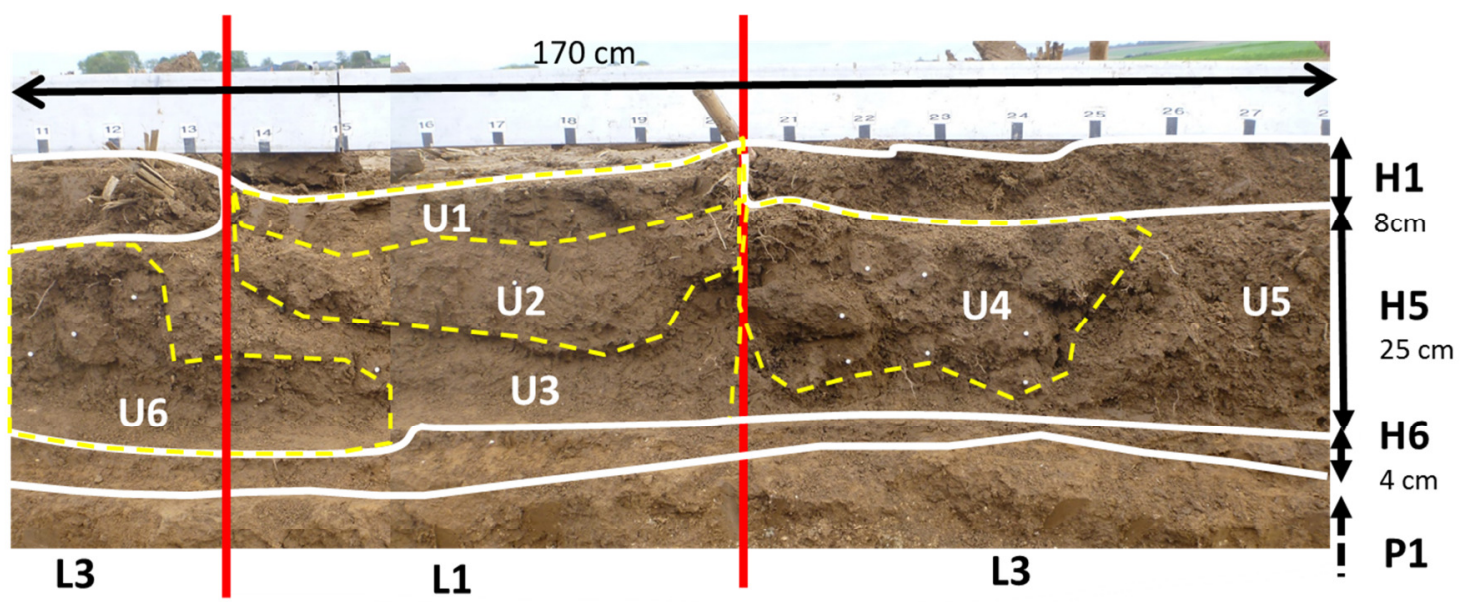

Photo : Vincent Tomis

Figure 1. Principle of the stratification of the observation face of a soil pit from an example in plough tillage system. Vertical partition: $\mathrm{H1}$ to $\mathrm{H} 4=$ secondary tillage operations, $\mathrm{H} 5=$ primary tilled horizon not affected by secondary tillage, $\mathrm{H6}$ and $\mathrm{H} 7=$ older tilled horizons when ploughing was deeper and $P I=$ pedological layer, called $H 8$ if it is affected by tillage (subsoiling). Lateral partition: L1 part of the profile located under the wheel tracks of field operation(s) done after secondary tillage, L2 part of the profile located under the wheel tracks that is not visible on the soil surface, generally created during secondary tillage and L3 part unaffected by the wheels since the last ploughing. Morphological units $(U 1, U 2 \ldots)$ have a homogeneous soil structure. 


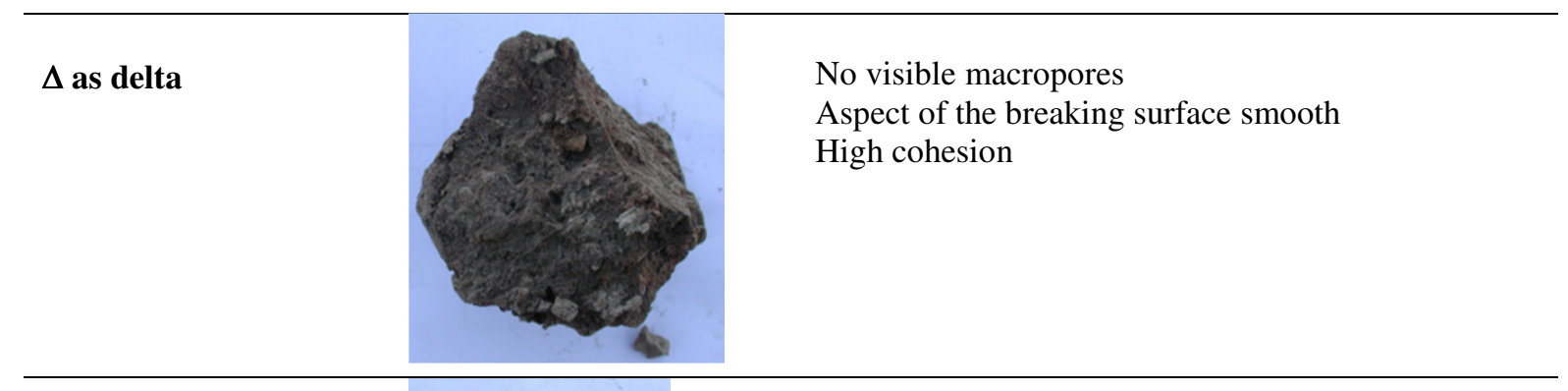

$\Gamma$ as gamma

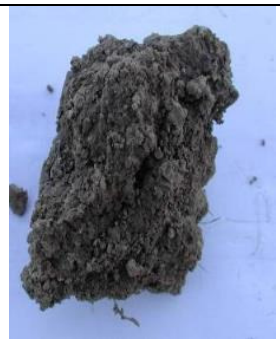

High structural porosity with visible aggregates

Rough surface

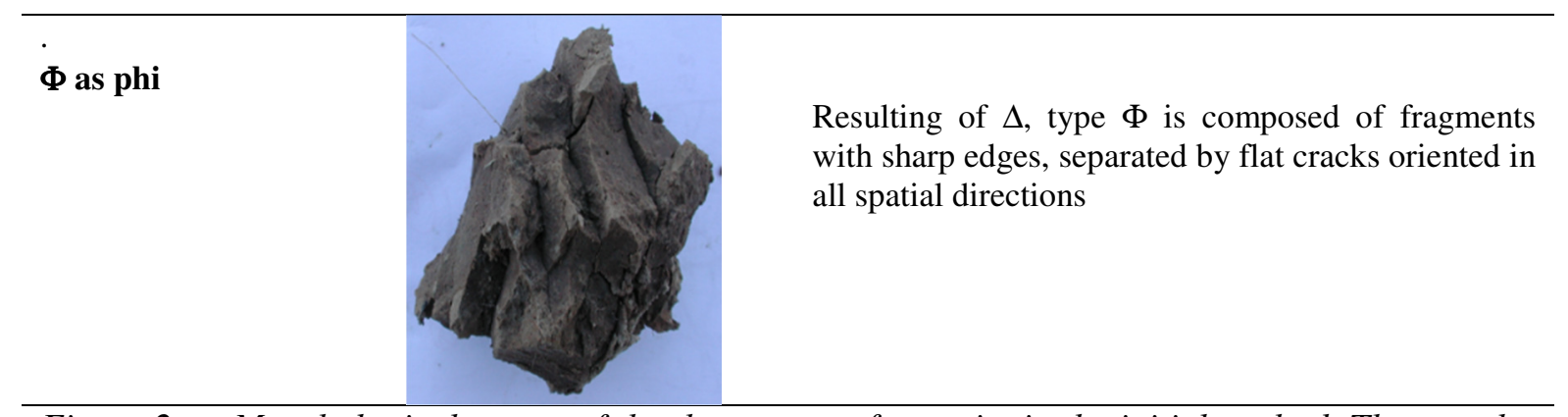

Figure 2a. Morphological aspect of the three types of porosity in the initial method. The samples were observed in a silty loam at Estrées-Mons (Northern France)

$P$ as platy

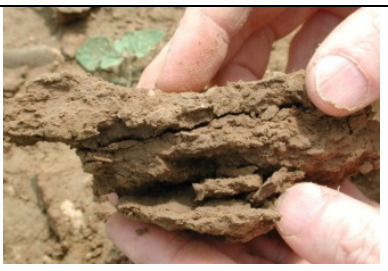

Resulting of $\Delta$, type $\mathrm{P}$ is characterised by a network of horizontally-oriented cracks.

Figure 2b. Morphological aspect of the type of porosity $P$, which supplements the three original types. The sample was observed in a silty loam at Estrées-Mons (Northern France) 


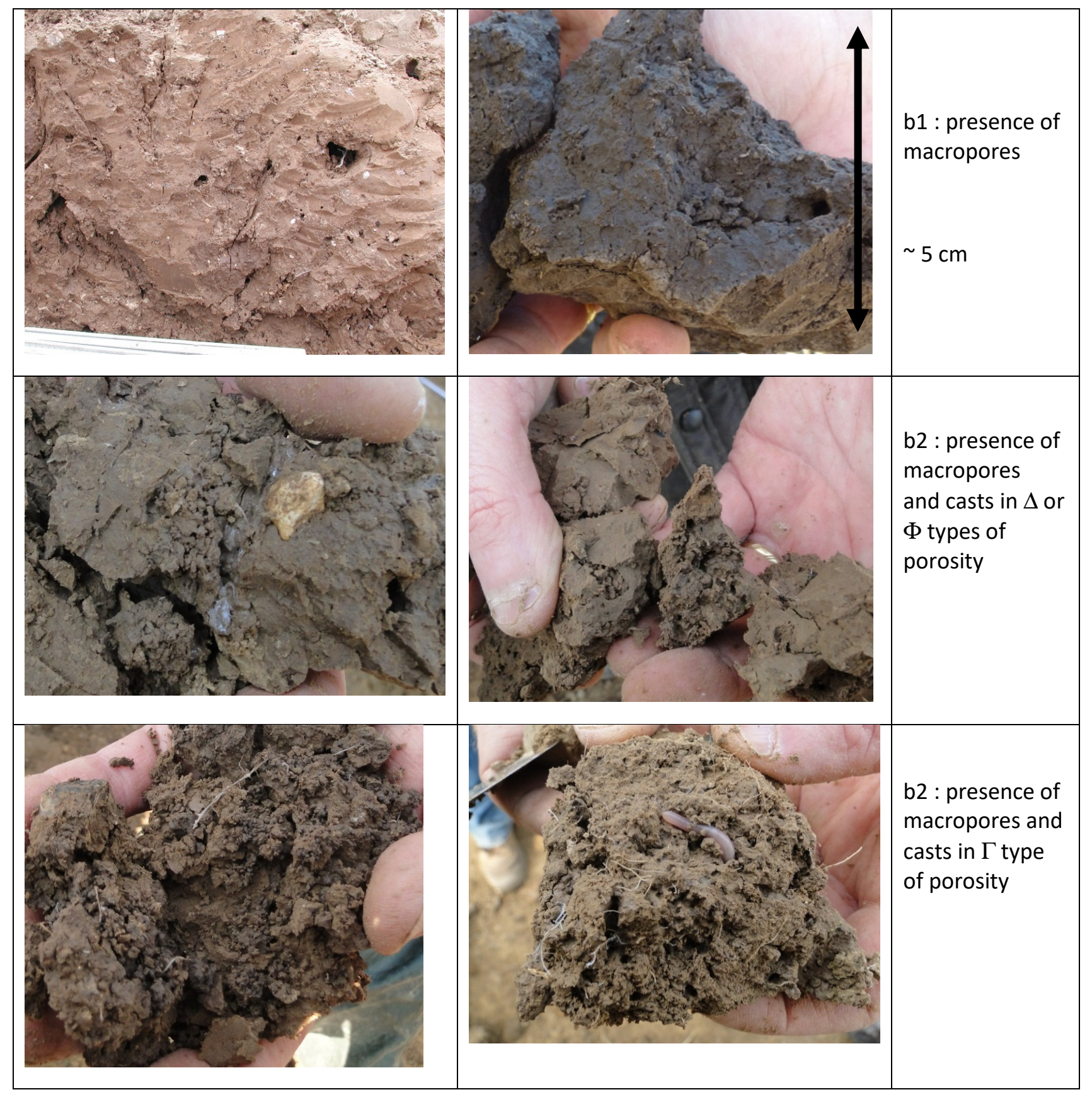

Figure 3. The biological criterion illustrated for both b1 and b2 and for different types of porosity with the improved method 


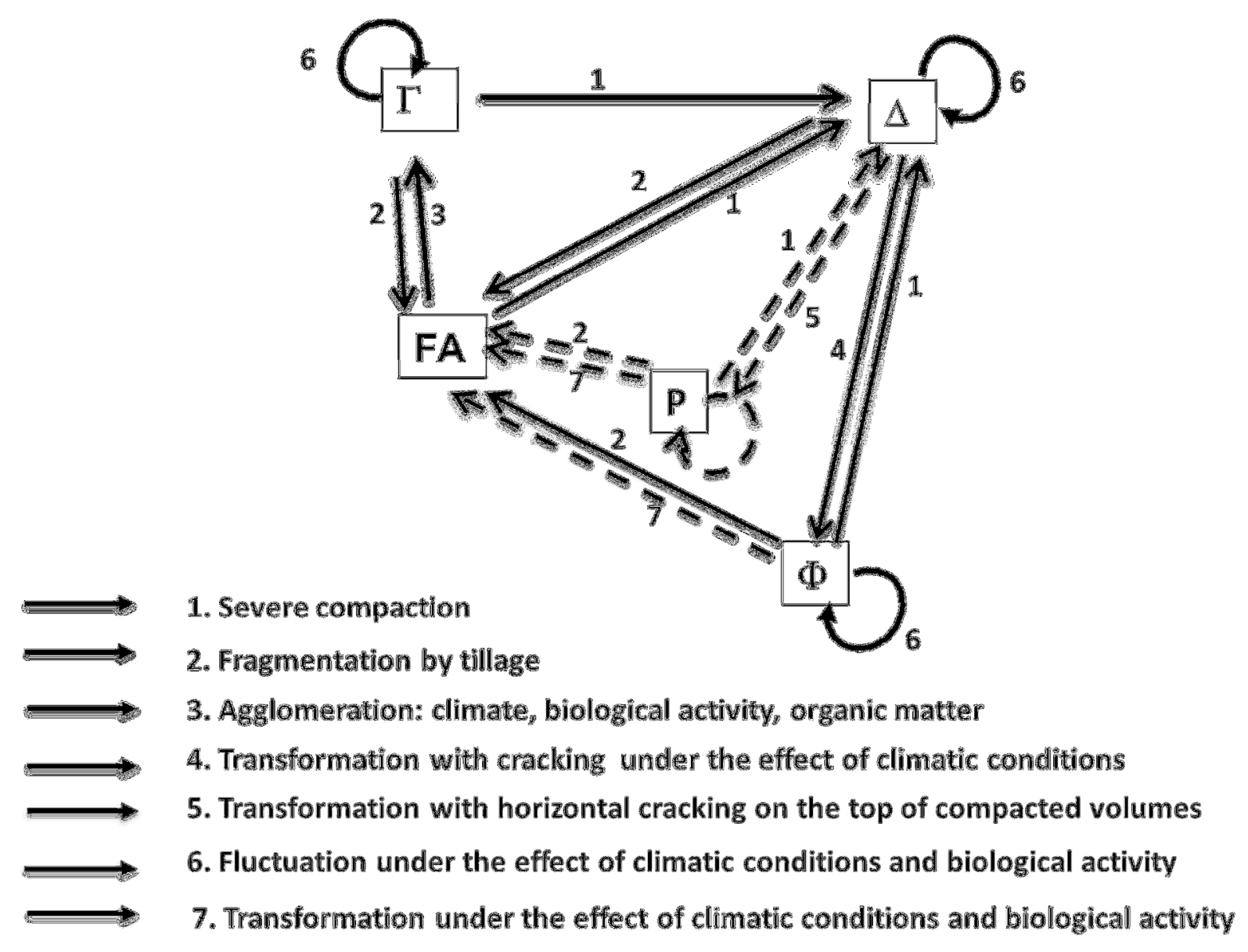

Figure 4. Changes in structural porosity over time; FA is fine aggregates; the initial model is represented by solid lines. The amendments proposed in the modified model are represented by dotted lines 


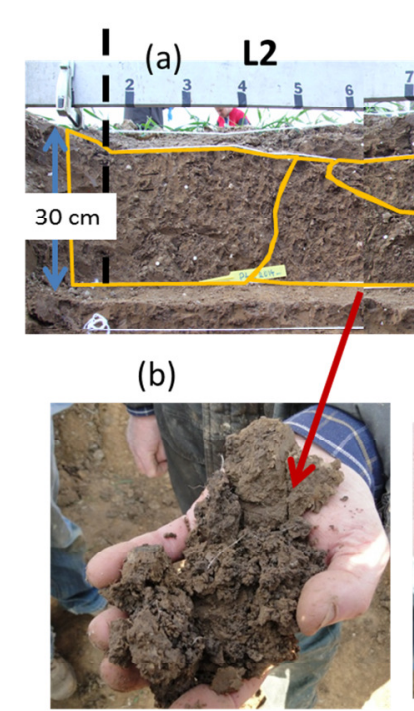

$c \Gamma \mathrm{b} 2$
MONS-RT-HC

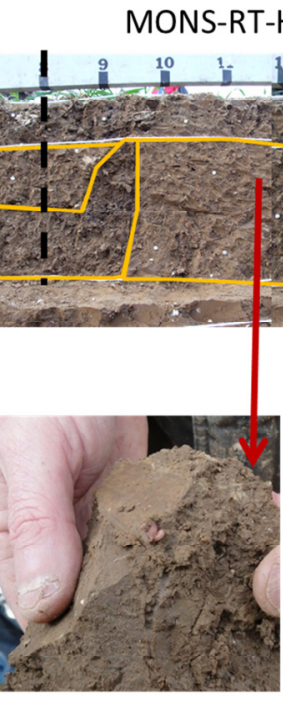

$c \Delta$
${ }_{15}{ }^{5}$

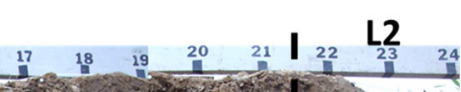

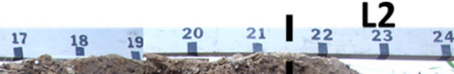
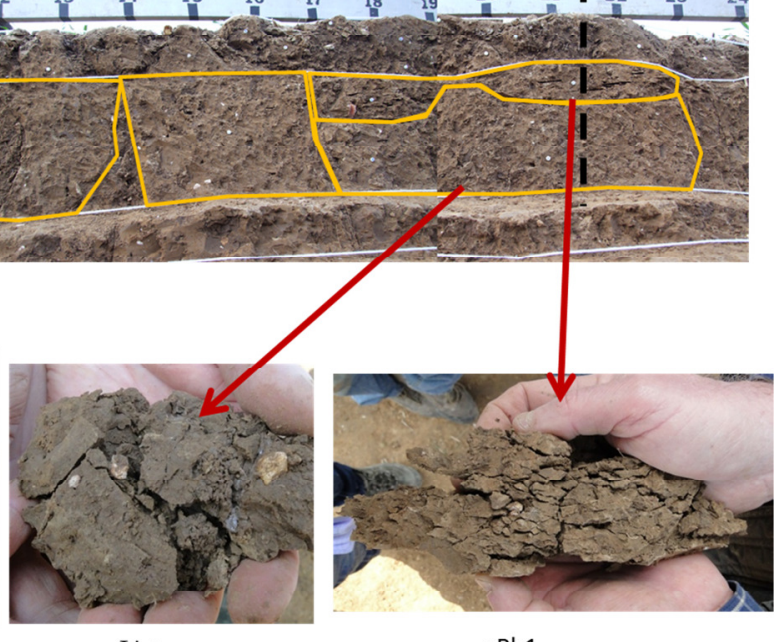

$c \Phi b 1$

$\mathrm{cPb} 1$

(c) Initial method

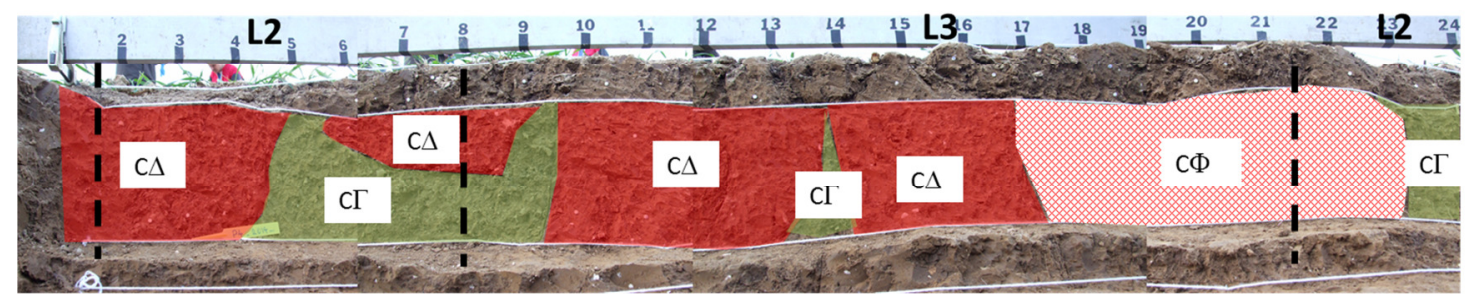

(d)

Modified method

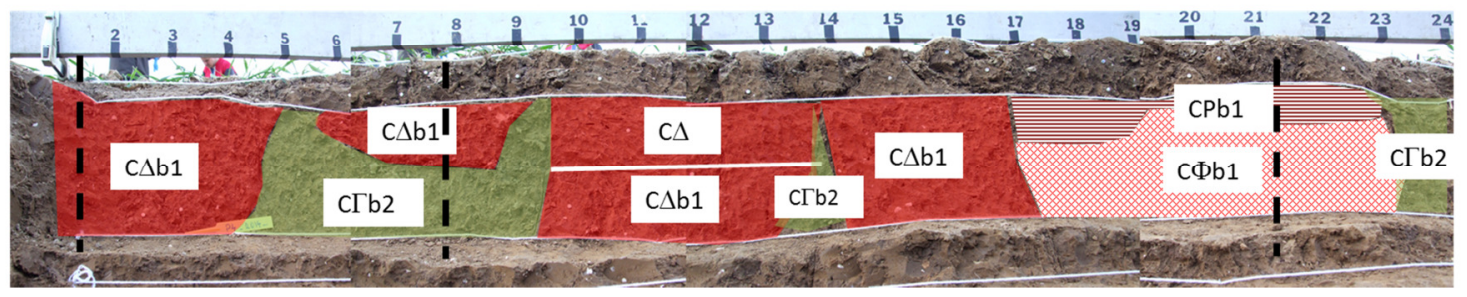

Figure 5. Cultural profiles observed on a $240 \mathrm{~cm}$-wide profile in Estrées-Mons: picture of the profile (4a); zoom on some structural states (4b); drawing using the initial method (4c); drawing

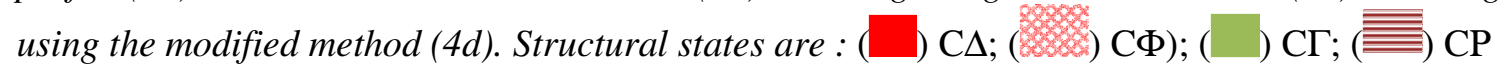
and bioturbation is indicated on each unit 


\section{(a)}

PAR-NT-CS

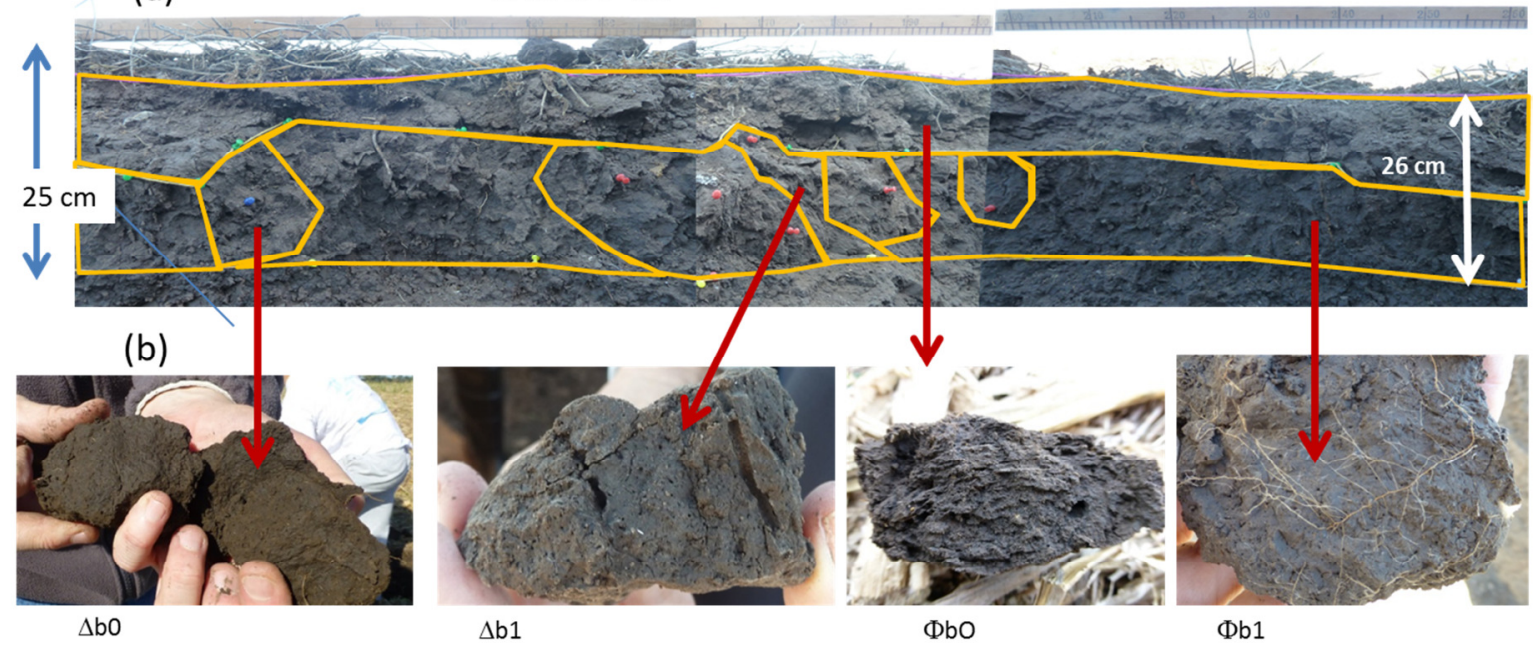

(c) Initial method

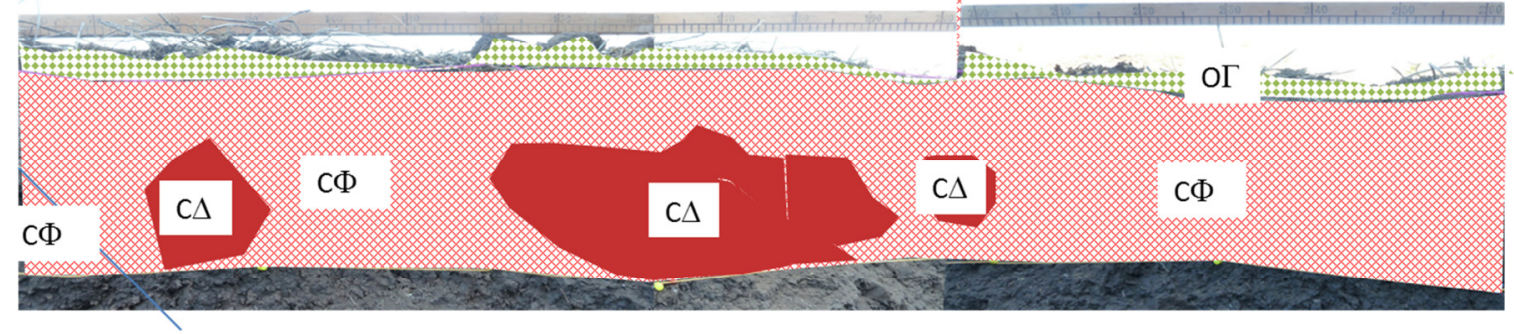

(d) Modified method

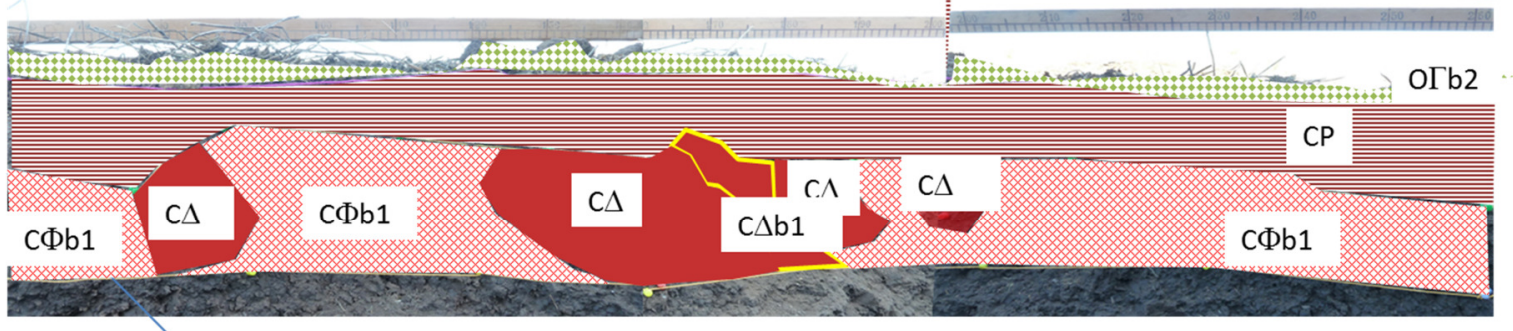

Figure 6. Cultural profiles observed on a $160 \mathrm{~cm}$-wide profile in Parana: picture of the profile (4a); zoom on some structural states (4b); drawing using the initial method (4c); drawing using the

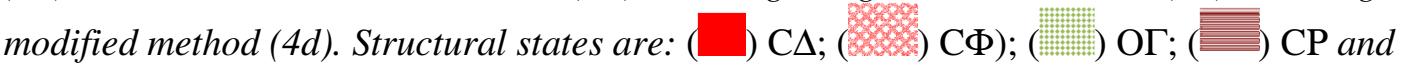
bioturbation is indicated on each unit 


\begin{tabular}{|c|c|c|c|}
\hline $\begin{array}{l}\text { Name of the } \\
\text { experimental } \\
\text { treatment }\end{array}$ & $\begin{array}{l}\text { Horizon } \\
\text { and depth } \\
(\mathrm{cm})\end{array}$ & Profile structure maps & \\
\hline $\begin{array}{l}\text { KER-NT-M } \\
\text { No till with } \\
\text { mineral } \\
\text { fertilisation } \\
200 \mathrm{~cm} \text { width }\end{array}$ & $\begin{array}{l}\text { H0: } 0-10 \\
\text { H5: } 10-27\end{array}$ & 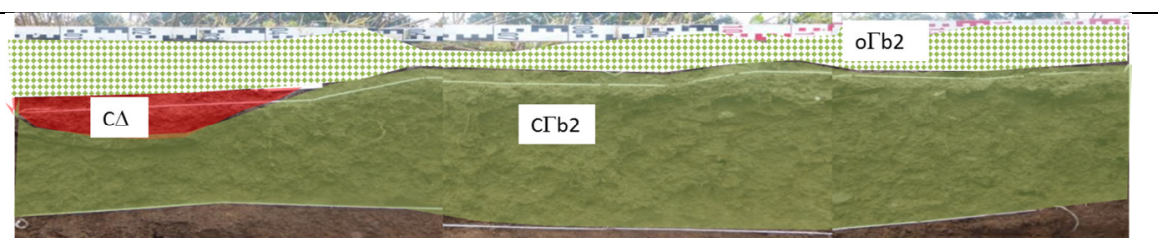 & $\begin{array}{l}\text { H0: fragmented soil structure with high presence of biological } \\
\text { macropores and casts } \\
\text { H5: soil structure is continuous ( } \mathrm{C} \Gamma \mathrm{b} 2: 95 \%) \text { with the presence of a } \\
\text { significant structural porosity, mainly due to earthworms activity } \\
\text { (macropores and casts) }\end{array}$ \\
\hline $\begin{array}{l}\text { KER-NT-P } \\
\text { No till with } \\
\text { poultry manure } \\
200 \mathrm{~cm} \text { width }\end{array}$ & $\begin{array}{l}\text { H0: } 0-10 \\
\text { H5: } 10-27\end{array}$ & 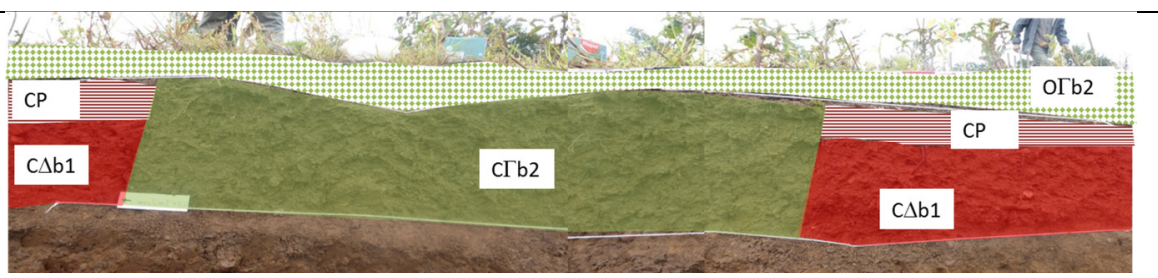 & $\begin{array}{l}\text { H0: lumpy soil structure with high presence of biological } \\
\text { macropores and casts } \\
\text { H5: } 40 \% \text { of the horizon were highly compacted }(\mathrm{C} \Delta \mathrm{b} 1 \text { and } \mathrm{CP}) \text { with } \\
\text { platy soil structure located at the top of the } \mathrm{C} \Delta \mathrm{b} 1 \text { zones and presence } \\
\text { of some biological pores in } \mathrm{C} \Delta \mathrm{b} 1 \text { zones: } 60 \% \text { of areas has a } \\
\text { continuous soil structure and high structural porosity }(\mathrm{C} \Gamma \mathrm{b} 2)\end{array}$ \\
\hline $\begin{array}{l}\text { LOND-NT } \\
\text { No-till } \\
200 \mathrm{~cm} \text { width }\end{array}$ & $\begin{array}{l}\mathrm{HO}: 2 \text { to } 5 \\
\mathrm{H} 5: 5-30\end{array}$ & $10\left(\begin{array}{llllll}0 \Gamma \mathrm{b} 2 \\
\mathrm{c} \Delta \mathrm{b} 2\end{array}\right.$ & $\begin{array}{l}\text { H0: continuous mulch of residues mixed with fragmentary soil } \\
\text { structure and presence of bioturbation } \\
\text { H5: soil structure is continuous and massive with high presence of } \\
\text { macropores and casts }(\mathrm{C} \Delta \mathrm{b} 2: 74 \%) \text {. } \\
\text { Presence of some compacted volumes with few biopores (C } \Delta \mathrm{b} 1) \\
\text { underneath the mulch and corresponding to wheel tracks }\end{array}$ \\
\hline $\begin{array}{l}\text { LOND-CTD } \\
\text { Conventional } \\
\text { tillage with disc } \\
\text { ploughing } \\
200 \mathrm{~cm} \text { width }\end{array}$ & $\begin{array}{l}\text { H1: } 0-10 \\
\text { H5: } 10-40\end{array}$ & 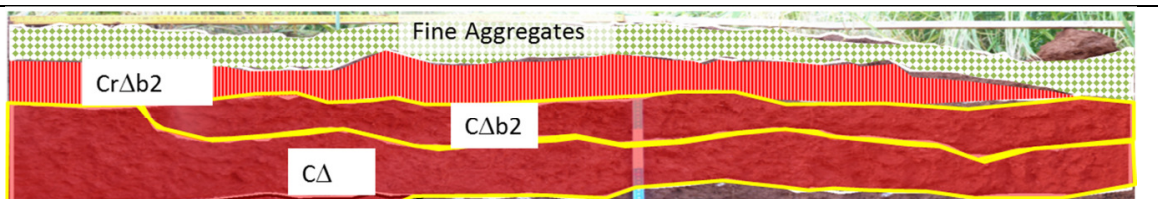 & $\begin{array}{l}\text { H1: a fragmentary layer composed of fine aggregates } \\
\text { H5: H5 layer is highly compacted especially at the bottom }(\mathrm{C} \Delta: \\
48 \%) \text {. At the top, current regeneration }(\mathrm{C} \Delta \mathrm{b} 2 \text { and } \mathrm{Cr} \Delta \mathrm{b} 2: 52 \%) \\
\text { under the effect of climate and biological activity with presence of } \\
\text { macropores and some vertical cracks just at the top }\end{array}$ \\
\hline $\begin{array}{l}\text { LYON-NT } \\
\text { No-till } \\
300 \mathrm{~cm} \text { width }\end{array}$ & $\begin{array}{l}\text { H0: } 0-3 \\
\text { H5: } 3-25 \\
\text { H8: } 25-35\end{array}$ & 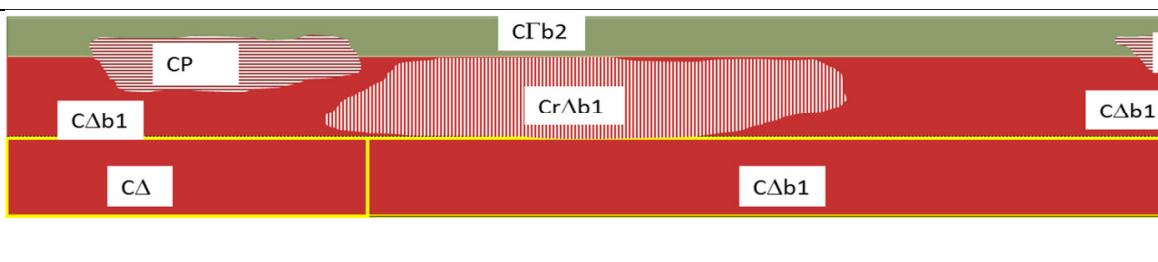 & $\begin{array}{l}\text { H0: very loose soil structure due to crop residues and biological } \\
\text { activity on the surface. } \\
\text { H5: high compaction with a continuous soil structure. Presence of a } \\
\text { platy soil structure at the top of a } \mathrm{C} \Delta \text { zone and highly compacted } \\
\text { area perforated by earthworm channels in the bottom part of } \mathrm{H} 5 \\
\text { H8: high compaction is observed with a discontinuous presence of } \\
\text { earthworm macropores (C } \Delta \mathrm{b} 0 \text { and } \mathrm{C} \Delta \mathrm{b} 1)\end{array}$ \\
\hline
\end{tabular}




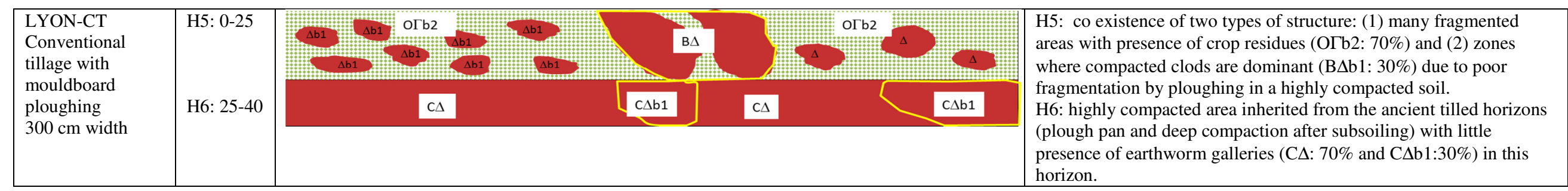

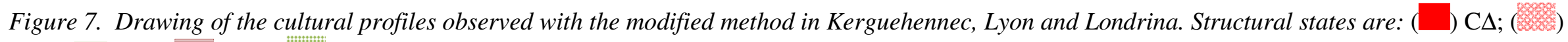

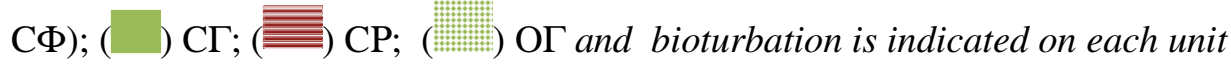

